\title{
ミース・ファン・デル・ローエの煉瓦造田園住宅案のパースと平面図の関係 RELATIONSHIP BETWEEN PERSPECTIVE DRAWING AND PLAN OF THE BRICK COUNTRY HOUSE BY MIES VAN DER ROHE
}

\author{
佐野潤一* \\ Junichi SANO
}

\begin{abstract}
Between a perspective view and a ground plan of the Brick Country House by Mies there are a number of discrepancies. In the previous studies, for instance, it is said that they reflect different planning stages, the ground plan represents the final one and the perspective does the earlier. However more concrete relationships between them are still unknown. In this paper the relationships were derived from some clues in the two drawings, the dark window of the upper floor in the perspective and so on.
\end{abstract}

Keywords: $\quad$ Mies, Brick Country House, Concrete Country House ミース，煉瓦造田園住宅，コンクリート造田園住宅

\section{1.はじめに}

ルートヴィッヒ・ミース・ファン・デル・ローエ $(1886-1969$ 年、 以降ミース)による革新的な五つの計画案の最後である煉瓦造田園 住宅案(1924 年)のパースと平面図は 1924 年春、ベルリン芸術展に初 めて登場し、1925 年マンハイムにおいても展示された(図 1)1)。煉 瓦造田園住宅案は「革新的であり、かつ過渡的である。それ以上に、 進歩であり、同時に後退である」 ${ }^{2)}$ と言われるように、ミースの建 築手法の形成過程を示す極めて興味深いものであると言えよう。

しかしながら、このパースと平面図は整合していない。つまり、 パースから推定される平面と平面図とが一致しない。既往の研究に おいて、パースの煉瓦壁の手の込んだ表現と平面図のかなりラフな 描き方の違いを根拠に、平面図が展覧会を前にした時間的制約の下 で新たに作成された、つまり両者は別々の段階の姿であるとの説な どがあるが 3)、両者の具体的関係、及び著名な平面図(図 1 の平面図) の出現の経緯は不明のままである。

そこで、パースと平面図にみられるいくつかの不可解な要素を手 がかりに、また強い関連性が指摘されているコンクリート造田園住 宅案(1923 年、図 2) 4) との関係などからパースと平面図の具体的な関 係、及び平面図の出現経緯の解明を試みる。この問題はバルセロナ・ パヴィリオン(1929 年)で実現する、独立した壁体の構成というミー スの手法の形成過程の解明につながっている。

\section{2. 残されているパースと平面図}

残存するオリジナル資料はパースと平面図の写真(図 1)である5)。 なおパースと平面図が上下に配置された図は掲載の資料によって微 妙に異なる。例えば、平面図における煉瓦壁と暖炉の煙突の形状は 全く変わらないが、ガラスの開口位置や屋根スラブの軒先を示寸線 は、その都度加筆された可能性があり 6)、資料ごとにかなり異なる 7)。パースについても、少なくとも二種類あるが、トリミングによる 幅の違いであり、元の図は同一と考えられる 8)。そこでこのパース と、平面図については資料によって変わることのない煉瓦壁と煙突 を分析対象とし、問題の解明を試みる。

\section{3. パースと平面図にみられる不可解な問題}

\section{1 パースにみられる唯一の暗い空}

これまで言及されていないが 9)、パースにおいて、なぜか二階の 暖炬煙突左の開口部のガラス面だけが暗い（図1 のパース)。同一方 向の他の全てのガラス面は白いことを考えると、極めて不可解であ る。影が描かれていることから全体は昼間の姿であるが、ガラス面 は昼と夜の姿を同時に示しているようでシュルレアリズム絵画を思 わせる 10)。

この暗い空の他の開口部については、ガラス面の左右が全て影な どの暗い面であり、描画上の効果から明るい面と暗い面が隣り合う

\footnotetext{
$*$ 摂南大学理工学部建築学科 教授 $\cdot$ 博士 (工学)
} 
ように配慮された結果との推測も可能である。開口部の右側の暖炉 の明るい面との明確なコントラストを狙っているという解勫である。 しかしながら、左右の壁は確かに白っぽいが、煉瓦を表現した水平 な縞模様が描かれており、空との明度は異なる。そこでこのことを 確かめるために、このガラス面を他の空と同じ白いものに変えてみ ると(図 3 )、極めて自然な姿に見える。つまり暗い根拠が描画上の 問題からきているとは考えられない。

そこで、この開口部を詳細に見ると、興味深いことが分かる。他 の部分に比べて、かなりラフに描かれている(図 4)。このことは、

この開口部だけが他の窓とは異なる段階、つまり後から描かれたこ とを窥わせる。

さらに興味深いことには、この暗い空の白っぽい縦枠に煉瓦壁の 表現として描かれた水平な筋の断片が微かにではあるが、確認でき る(図 4：○、図 5)。このことは、煉瓦壁として描かれていた部分 が、一旦消され、その後に縦枠部分だけを残してガラス面だけが黒 く塗りつぶされ、消し残された筋が縦枠に微かに見えていることを 示している。つまり、暗い空の元の姿はその左側の煉瓦壁と同じも のであった。空の不揃いが生じるにもかかわらず、またパースの中 央部にもかかわらず、このような変更がなされたことは、そのまま ではかなり重大な不都合、つまり平面図との大きな矛盾が生じるこ ととなることを示していると考えられる。

\section{2 平面図にみられる外部へ突出する唯一の壁}

ミースは 1924 年当時この住宅の平面について、「煉瓦造のこの住 宅は材料の形への影響を示した前例(コンクリート造田園住宅案 : 筆 者)とは正反対の姿を示している。私はこの住宅の平面において、従 来の囲まれた部屋という概念を捨て、個室の連なりではなく、一つ ながりをなす空間の効果を狙っている。壁は囲む性質を緩め、住宅 の諸機能を示すことだけに役立っている。」11) と述べている。具体的 には、壁が部屋を四角く囲み込むのではなく、独立した一枚の壁が 少しずつズレて、行き交うことで、空間を緩やかに限定している。 その結果、緩やかに限定された空間のコーナーでは、二枚の壁が少 し離れて直角に向き合っている。つまり壁の端部が現れ、突出する のである。しかしながら、奇妙なことに、パースにみえる外観にお いては、煉瓦壁はコンクリート造田園住宅案 (図 2 ) 同様、部屋を四 角く囲むように直角に曲がり、平面図にみられる内部間仕切壁のよ うな突出は見えない。暖炉の煙突（図 $6:$ E、F）は突出しているが、 それは直方体のマッシブな塊であり、全体はパースで見る限り「直 方体の塊の集合体」12）のように見え、壁体の構成とはかなり異質な 印象である。つまりパースは平面図と「同じプロジェクトとは思え ない」13)。煉瓦壁とガラスがコーナーで出会う箇所（例えば、図 6 : D) でも煉瓦壁は建物の輪郭内（図 6 : 玄関周り以外の太線）に留ま っており、突出はなく、平面図にみられる内部の間仕切壁のような 構成は、少なくともパースにおいては全く見えない。例えば、当時 のヘリット・リートフェルト $(1888-1964$ 年)によるシュレーダー邸 (1924 年)にみられるような外観における壁の突出は全く見えない のである。

ところが、内部間仕切壁と同じように、突出し端部を見せている 壁が平面図の立関ホール周りに一つだけある(図 6:A ${ }^{14)}$ 。なぜこの 部分の壁だけが他と異なり、外部へ突き出ているのか。

また、この玄関ホール周りの壁の構成は、影響関係が指摘されて

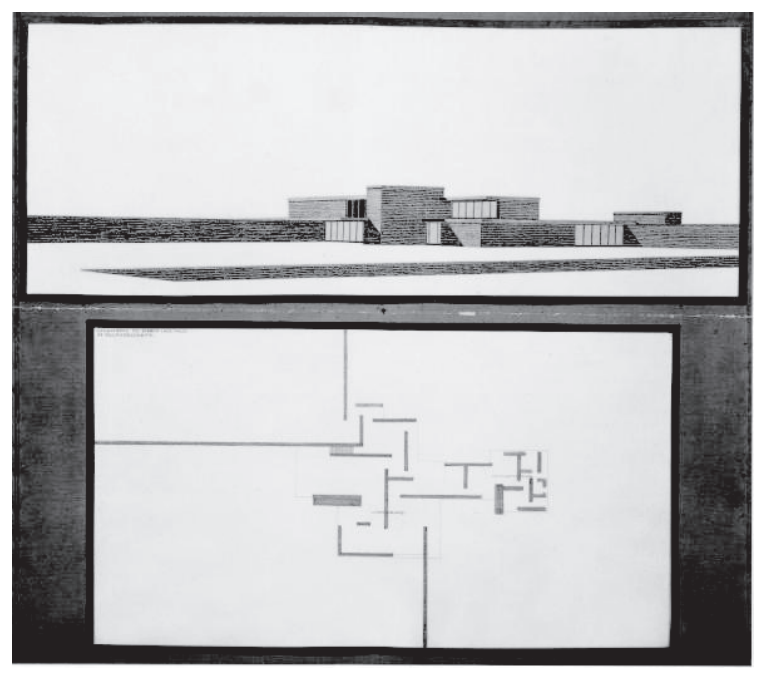

図1煉瓦造田園住宅案の外観パースと平面図 1924 年

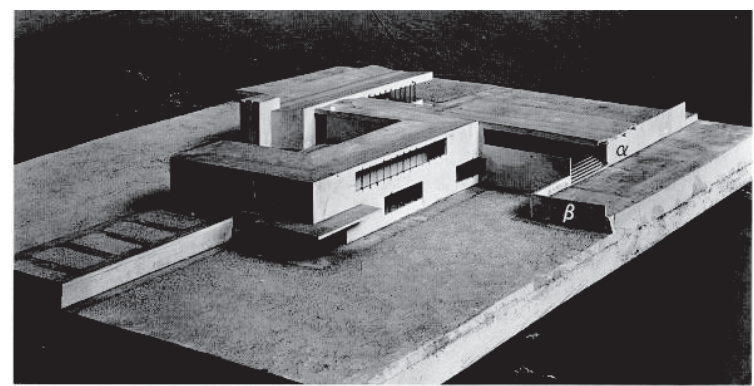

図2 コンクリート造田園住宅案 1923 年(文字は筆者)

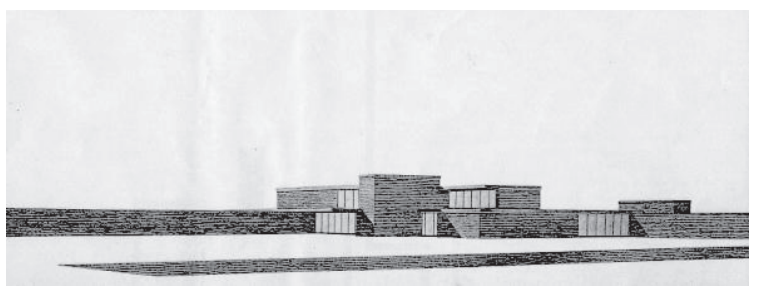

図3 煉瓦造田園住宅案の暗い空を変更したパース

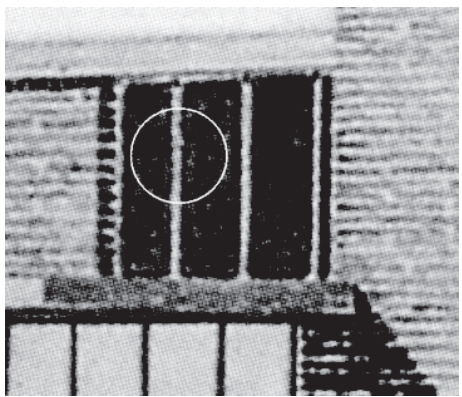

図4 煉瓦造田園住宅案の暗い空 (○は筆者)

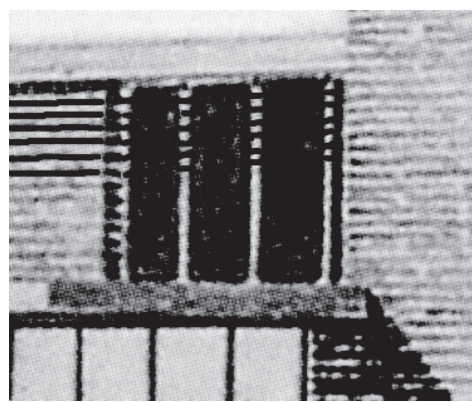

図5 暗い空の縦枠の縞(太線は筆者) 
いるテオ・ファン・ドゥースブルフ (1883-1931 年)の絵画「ロシ アダンスのリズム」(1918 年、図 7) ${ }^{15)}$ に最も似ている部分である。 さらにパースと平面図の大きな矛盾が生じる部分のひとつでもある。 平面図（図 6）の玄関ホール左下の階段は上り方向が不明である。 例えば、玄関ホールから上がるとすれば、二階はリビングの開口部 位置（図 $6: G$ ) まで出ている必要がある。そこでパースの二階の暗 い空は一階の開口部の真上あたり（図 6:G）に位置することとなる。 しかしこの暗い空の左の煉瓦壁を支えることとなる位置（図 $6: \mathrm{H}$ ) に全く壁が見当たらず、構造的に煉瓦壁が乗ることは不可能である。 反対にリビング左上から二階に上がるとした場合、二階の暗い空の 位置は上方に延びる煉瓦壁（図 6：B）の下方への延長線（図 6：I） 上と考えると、構造的には可能性があるかもしれない。しかしなが ら、一階の屋根がこの位置（図 $6:$ I) まで掛かっていることになる ため、階段の途中で階段空間の高さが不足し、頭を打つようなこと となってしまう。つまり、玄関ホール周りの平面図は明らかにパー スと整合しない。このことは、平面図におけるこの玄関部分がパー スに描かれている外周部を示寸設計段階の姿とは異なるものである ことを示している。パースにみえる外観の、壁端部が突出するので はなく四周を連続的に囲む壁という姿は、むしろ先行するコンクリ 一ト造田園住宅案 (図 2) の外観に近いことを考えると、壁体の構成 という平面図の玄関周りのデザインは、「塊の集合体」のパースより も後にデザインされたものであると考えられる。

さらにリビングの大きな暖炉（図 $6: \mathrm{E}$ ）から下方の壁の配置が、 独立した壁がズレて、行き交う開放的な玄関ホール周りの構成とは かなり異なっている、つまりこの部分では矩形の空間の輪郭を破る ことなく壁が配置されていることも、玄関ホールとリビングのこの 部分が異なる段階のものであることを示唆している。

\section{3. パースにみられる敷地の傾斜}

煉瓦造田園住宅案とコンクリート造田園住宅案 (図 2)の敷地はポ ツダムのユンガフェルン湖岸近傍に位置し、二つは同一もしくは近 接した敷地に計画されていたとされる ${ }^{16)}$ 。

さて、コンクリート造田園住宅案の模型写真(図 2) からその敷地 が緩やかな傾斜地であることが分かる。なお建物の断面形式は敷地 の高低差から立関(図 2: $\alpha$ の左) が二階にある構成(図 8) となってお り、敷地の段差を処理する擁壁(図 2: $\alpha, \beta$ ) が作られている。煉瓦 造田園住宅案とコンクリート造田園住宅案の関係を考えると、煉瓦 造田園住宅案の敷地も傾斜地である可能性が強い。パース(図 9) を 見ると、手前に低い擁壁(図 9：a ) があり、この擁壁が敷地に勾配 があることを示している。さらにこの擁壁の左端の斜め部分 (図 9 : b ) は図の左から右へと地面が下っていることを示している。なお芸 術展のカタログに掲載されたスケッチ(図 10)においてもこの擁壁 を示すと思われる線(図 10：a)があり、その右端(図 10：d）には擁 壁の煉瓦側面を表すジグザク線が認められる。このスケッチにおい ても右側が低くなっている。

パース（図 1,9）とこのスケッチ（図 10）は同じ場面を描いてい ると考えられるので、リビングや玄関のある部分からサービスゾー ン(図 6)へと敷地が下がっていることはほぼ確実であろう。

煉瓦造田園住宅案パースの擁壁の姿 (図 9: a, b ) は玄関前の敷地 （図 $6: B$ と J で区画された部分）地盤が少なくともサービスゾーン （図 6:D, F 側）よりも高かった可能性を示唆する。とすれば、玄関

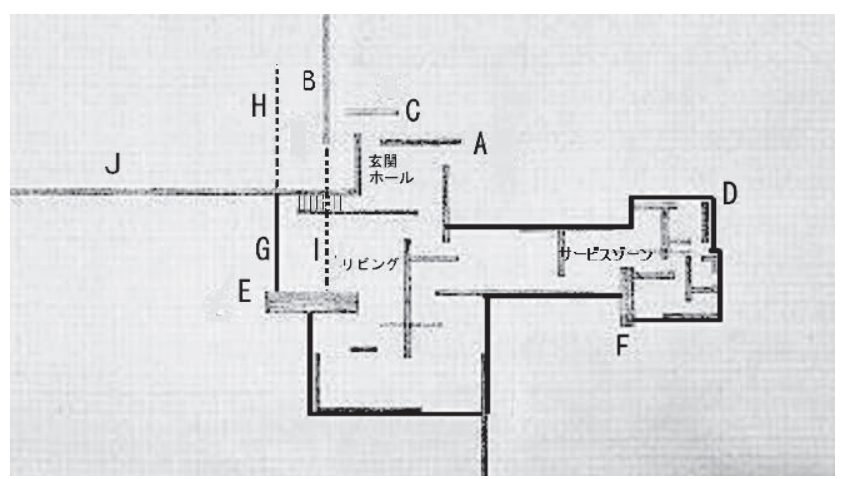

図 6 煉瓦造田園住宅案の平面図の分析図 1

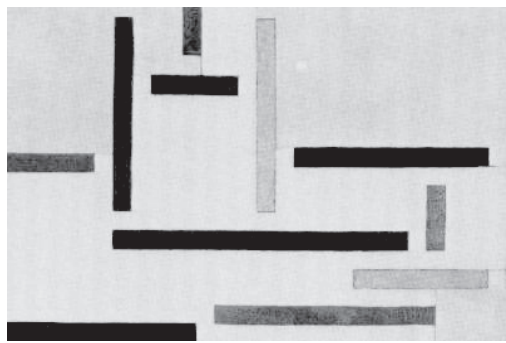

図 7 ドゥースブルフのロシアダンスのリズム 1918 年(部分)

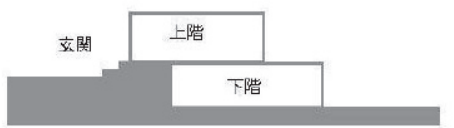

図 8 断面構成

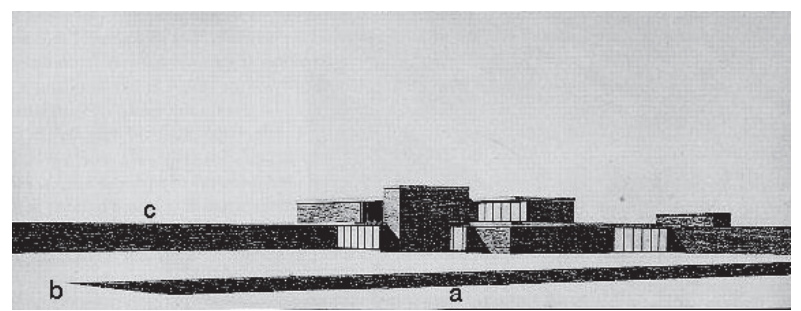

図 9 煉瓦造田園住宅案の擁壁 (文字は筆者)

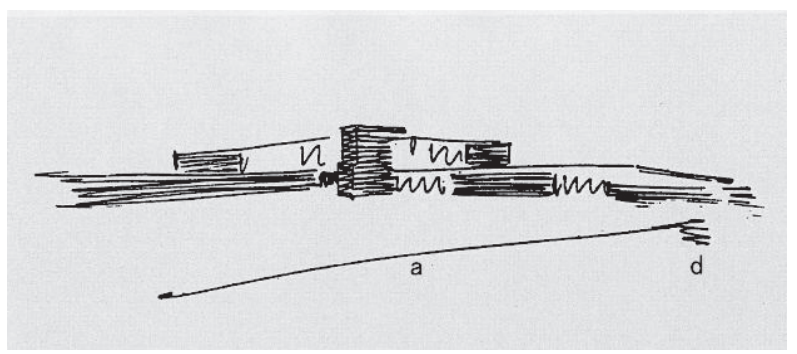

図 10 カタログの煉瓦造田園住宅案のスケッチ (文字は筆者)

前の敷地とサービスゾーンの敷地を隔てる壁（図 6：B）は敷地を隔 てる単なる壁ではなく、敷地の高低差を処理する擁壁であると考え られる。

このことから、二つの壁(図 $6: \mathrm{B}, \mathrm{J}$ ) は、コンクリート造田園住宅 案にみられるような擁壁(図 $2: \alpha, \beta$ ) である可能性が考えられる。 つまり敷地を隔てる単なる壁ではなく、敷地の高低差を処理する擁 壁であった。

これらのことを考え合わせると、コンクリート造田園住宅案 (図 
2) 同様、煉瓦造田園住宅案においても、ある段階では玄関が上階に 位置する断面構成（図 8) であった可能性が導出される。なお、こ のような断面構成はミースの第一作リール邸(1907 年)で既に実現 し、後のトゥーゲントハット邸 (1928-30 年)やゲーリッケ邸案 (1932 年) 等においてもみられる、傾斜地におけるミースの常套手法と言う べきものであったこともこの可能性を強める。

\section{4. パースと平面図の関係、及び平面図の出現経緯}

以上三つの問題の考察結果を踏まえて、パースと平面図の関係等 を考える。まず、二階の暗い空は、元は煉瓦壁であった。そこに描 かれていた何かが消されたことは、そこに平面図(図 1 の平面図) と 大きな食い違いを示すものが描かれていた可能性を示す。そして二 階に見えていては平面図と最も矛盾寸るものとして玄関が考えられ る。二つ目には、平面図の玄関部分だけが壁の外部への突出という 点で平面図の他の外周部分とは異質であり (図 6)、この部分が後か らデザインし直された可能性がある。つまり玄関周りは一階の平面 図において新しく描かれた。三つ目には、敷地が傾斜地であり、玄 関前の部分が高い位置にあった可能性がある。

これら三つの分析結果全てが玄関部分が上階にあった可能性を示 唆する。暗い空の位置には、玄関があり、形は不明であるが玄関周 りの煉瓦壁が見えていた。そしてパースの左方に伸びている煉瓦壁 (図 $9:$ c) は平坦な敷地を単に隔てる壁ではなく、傾斜地を造成した 擁壁であったことになる。同一もしくは近傍の敷地に計画された、 先行するコンクリート造田園住宅案にみられる屋外の壁(図 2: $\alpha$, $\beta$ ）は擁壁、厳密には下部が擁壁で上部がパラペットであったことも、 この推測を強める。つまり煉瓦造田園住宅案においても、コンクリ 一ト造田園住宅案 (図 2) 同様、この壁 (図 9：c) は上部がパラペット となっており、玄関前の地盤から階段で少し上がって建物に入る断 面形式(図 8)であった可能性が導かれる。

以上のことからは、次のようなパースと平面図の関係、及び平面 図の出現経緯が推測できる。

まず、パースに描かれている外観に対応する平面、つまり図 1 の 平面図とは異なっていた平面では、玄関が二階にあり、左に延びて いる壁(図 9：c) は傾斜地を造成した擁壁であった。その後この案が 最終的にデ・スティル派的な構成、例えば、ドゥースブルフの絵画 「ロシアダンスのリズム」(図 7)のような構成に変更された ${ }^{17)}$ 。

平面図(図 1) がラフに描かれていることやパースと平面図の不整 合は、平面図がかなり急いで作成されたことを窥わせる。つまり、 例えば、展覧会出品までの時間的制約 18)などからパースの描き直し や大幅な変更はできなかったため、パースにみえる姿と大きな矛盾 が生じないように、パースに描かれている外周部の壁と㝕の基本構 成は変更せず、パースでは見えない側の外周部、及び室内の間仕切 り壁だけがデザインし直されることとなったと推測される ${ }^{19)}$

また、一つのパースと一つの平面図で計画内容を提示するために、 二階と一階を結合させる形で平面図が作り直された。つまり玄関が 一階に移された。この部分（図1の玄関ホール周り）だけはパース では見えない側にあるため、デ・スティル派的、つまりドゥースブ ルフの「ロシアダンスのリズム」(図 7)のように変更され、結果と

して他の外周部とは異なることとなった（図１の平面図）。

このような経緯において、一階平面図が設計変更され、建物の諸
要素、つまり煉瓦壁と暖炉煙突、さらに余白が太枠の中で絶妙なバ ランスをみせる20)、著名な平面図(図 1 の平面図)が出現したと考え られる。

元のパースでは二階の暖炉煙突の左側は玄関部分であり、煉瓦壁 が見えていた。しかし玄関が一階平面に描かれることとなったため、 その部分の立関を消寸必要が出てきた。そこで煉瓦壁の横縞模様が 消されたが、完全に消えなかったためか、ガラス面を黒く塗ること によって対処された（図1，4）。

\section{5. 結語}

もちろん、煉瓦造田園住宅案のパースと矛盾しない平面をこれら の分析結果から推定することは不可能である。しかし、パースや平 面図にみられる不可解な要素とコンクリート造田園住宅との関係か らは、特に不可解な要素の解釈を手がかりに、断片的ではあるが、 パースと平面図の関係、及び平面図の出現経緯についてのひとつの 推測が導かれた。

ポツダムのユンガフェルン湖岸近傍の傾斜地に当初計画されてい たものが、展覧会出品という事情から、急遽デ・スティル派の影響 などによる変更を伴い、手直しがなされた。その際、手の込んだパ 一スの描き直しを最小限とするために、パースでは見えない部分に おいて、最大限デ・スティル派的な構成に変更された。平面図は一 つという制限から、二階にあった玄関を一階に変更し、デ・スティ ル派的な構成で作り直されたものが著名な平面図（図1の平面図） であった。そしてパース上階の玄関を消すために、この部分が暗い 空に変更され、不可解な空が登場したのである。つまり、時間的制 約の中での展覧会出品という偶然の機会が、ミースのバルセロナ・ パヴィリオンに結実する建築手法を生み出す一つの契機となったと 考えられるのである。

少ない手がかりであり、その解勫には不確かな部分が少なくない が、これまでパースと平面図の矛盾の指摘に留まり、矛盾が出現し た経緯については全く言及されていないため、一つの可能性として、 ここに報告するものである。

注

1) 1925 年にマンハイムで展示された煉瓦造田園住宅案のパースと平面図の写 真(図 1) はヴォルフ・テーグトフによって発見された(Brick Country House, Project, 1924. Elevation and plan. Installation view of New Types of Architecture [Typen neuer Baukunst], Mannheim Municipal Art Gallery, Mannheim, Germany. 1925 : Tegethoff, Wolf, 'From Obscurity to Maturity: Mies van der Rohe's Breakthrough to Modern Movement' in Mies van der Rohe, CRITICAL ESSAY, ed., Franz Schulze, [New York, 1989], p. 54)。

2) Schulze, Franz, Mies van der Rohe,A Critical Biography (Chicago, 1985), p. 116.

3) 例えば、テーゲトフ説では. 平面図は最終案であり, パースはそれよりも前 に作成されていたものとされている (Tegethoff, Wolf, MIES VAN DER ROHE, The Villas and Country Houses [New York, 1985], pp. 38-39)。

4) Tegethoff, 'From Obscurity...,' op. cit., pp. 53-54.

5) 1925 年のマンハイム市芸術ギャラリーでの「新建築の展示」のカタログに ラフな外観スケッチ(図 10, Neumeyer, Fritz, MIES VAN DER ROHE,Das kunstlose Wort, Gedanken zur Baukunst [Berlin, 1986], p. 39)があり, 外観パースとほぼ対応するが,暖炬の煙突左の一階部分など部分的には様々 に相違がみられる。また 1938 年以降アメリカ,シカゴ事務所で 1960 年代, 出版に際して新たに描かれたいくつかの一階平面図がある(Tegethoff, MIES VAN DER ROHE, The Villas ..., op. cit., p.43)。

6)テーグトフは図面内容が伝わるように平面図の不鮮明な線にインクで加筆 したと述べている(Tegethoff, MIES VAN DER ROHE, The Villas ..., op. 
cit., p.39)。

7) 例えば,ドイツ,マンハイム,1925 年のマンハイム市芸術ギャラリーでの「新 建築の展示」において展示されたパースと平面図では,「ノイバベルスベル クの田園住宅の一階平面図」との文字が見える。しかしこの資料では軒の 線はサービスゾーンと下方リビング部のみが確認可能で,ガラスの線は見え ない。(Tegethoff, 'From Obscurity ...,'op. cit.)。また Mies in Berlin (eds. Terence Riley \& Barry Bergdoll,[New York, 2001])掲載の写真(図 1, p.195) にはパースと平面図との間に水平方向に折り目のような筋がある。また平 面図の左上隅には「ノイバベルスベルクの田園住宅の一階平面図」との文 字が見える。さらに平面図には一階屋根の軒を示寸線がみえるが, 立関と立 関ホールを囲む二枚の壁、及びリビングゾーンと右側のサービスゾーンを 繋ぐ上側の壁にはみえない。ガラスを示す線は下方の空だけにしか見られ ない。またテーゲトフの本(Tegethoff, MIES VAN DER ROHE, The Villas .... op . cit.)にあるもの $(3.1,3.2)$ はパースと平面図が単独で掲載されている。 平面図の左上隅には「ノイバベルスベルクの田園住宅の一階平面図」との 文字が見え上記のものと同一であると推定される。ただし軒の線は玄関以 外全てあり,ガラスも二重線ですべて描かれている。MoMA のカタログ( $A n$ Illustrated Catalogue of the Mies van der Rohe Drawings in MoMA, Part I : 1910-1937 vol. 1. ed., Arthur Drexler [New York, 1986] , p. 91) では図面以外の部分が黒い。平面図も左上隅の文字もない。しかし軒はほ とんど描かれている。

8) MoMA カタログの写真のパースの左右は,他のパースよりも長く,この写真 がこれまでのものとは異なるものであることが確認できる(Ibid., p. 91)。

9)テーゲトフはパース一階の角の部屋の壁とガラス壁の比率の不一致や煙突 とガラス壁の出会う位置のずれ, さらにはパース右側のもう一つの煙突へ の軒の小さな影から, 煙突の位置の食い違いなど詳細な指摘を行っている が、なぜか二階の暗い空については言及がない(Tegethoff, MIES VAN DER ROHE, The Villas..., op. cit., p. 38-39)。

10) 例えば、ルネ・マグリットの「光の帝国」（1953-54 年)では空は昼間であ るが,建物は夜間のように描かれている。

11) ミースによる 1924 年 6 月 19 日レクチャー原稿(Neumeyer, op. cit., p. 309)。

12) Schulze, Franz, Mies van der Rohe,A Critical Biography (Chicago, 1985), p. 116.

13) 高山正實『ミース・ファン・デル・ローエ、真理を求めて』鹿島出版会,2006 年, p. 28。

14)平面図の上,下,左へ延びる長い壁はあるが,これらはコーナーで空間を緩 やかに限定するものではない。C はガラス壁の位置が明確でない。

15) Schulze, op. cit., p. 115 .

16) ポツダムのユンガフェルン湖岸の二箇所が敷地とされている(Tegethoff, 'From Obscurity....,'op. cit., p. 52)。
17) コンクリート造田園住宅案は 1923 年春のベルリン芸術展に出品され,同年 10 月から 11 月のパリでのデ・スティル派建築展にもその模型が展示された。 一方煉瓦造田園住宅案は 1924 年春のベルリン芸術展に初めて出品されてい る。このような関係はミースが煉瓦造田園住宅案においてデ・スティル派 から何らかの影響を受けた可能性を示唆する(Ibid., pp. 38-39)。

18) 同上。

19)テーゲトフが指摘するようにパースに描かれているサービスゾーンの暖 炉煙突は平面図では左に大きく移動している(Ibid., p.39)。

20)この平面図の作成に黄金比が使用された可能性がある(図 11)。例えば,左 に延びる壁は図面側辺を黄金比に分割する位置にあり,またこの左に延びる 壁と下方に延びる壁で区切られる左下の矩形は黄金矩形であり,さらに下方 に延びる壁とリビングゾーンと右側のサービスゾーンをつなぐ部分の長い 壁が区切る右下の矩形も黄金矩形である。拙稿(佐野潤一: ミース・ファン・ デル・ローエによる煉瓦造田園住宅の平面図の構成における黄金比の使用, 日本建築学会計画系論文集第 603 号, pp. 205-209, 2006•5）参照。

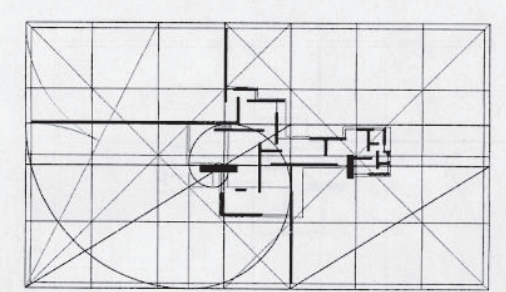

図 11 煉瓦造田園住宅案平面図における黄金比等の幾何学的関係

\section{図版出典}

図 1 Mies in Berlin, eds., Terence Riley \& Barry Bergdoll (New York, 2001), p.195

図 2 Tegethoff, Wolf, MIES VAN DER ROHE, The Villas and Country Houses (New York, 1985), 1.2

図 7 Schulze, Franz, Mies van der Rohe, A Critical Biography (Chicago, 1985), p. 116

図 10 Neumeyer, Fritz, Mies van der Rohe, Das kunstlose Wort, Gedanken zur Baukunst (Berlin, 1986), p.39

(その他の図は筆者作成)

（2011年 6 月 1 日原稿受理，2011年11月 4 日採用決定） 